\title{
On the Universal Value and the Socialist Democracy
}

\author{
Wei Huang \\ No.7-1 Unit 2 Buiding 1 \\ Qiyuan of Northern city \\ No. 18 Red and Yellow road, Jiangbei district \\ Chongqing 400020, China \\ E-mail: 58224679@163.com
}

\begin{abstract}
The universal value has become the focus of dispute among the common people and the thinking public. This paper, taking understanding scientifically the nature of the universal value as the starting point, analyzes the dispute of capitalism and socialism on the universal value and has found the reason resulting in the situation. And it further pointed out theoretically that the scientific way by which socialism wins the leading power is to establish the socialist democratic political system based on the proletarian universal value. Then, the paper, combining the history and reality, makes a bold imagination and analysis on how the universal system of socialist democracy can be practiced in the socialist counties or other world and draws the final conclusion that the universal socialist democratic system will help the socialism triumph over capitalism.
\end{abstract}

Keywords: Scientific understanding, Universal value, Create, Universal socialist democratic system, Liberation of all mankind

It is no doubt that democracy is a good thing! But there are different opinions about which democratic system is better and can be the more representative of the direction of the development of human society. In 2008, Obama and Hillary performed well and caught numerous eyeballs in the Democratic Party primary election of the U.S. presidential election. Such an African origin black as Obama and a woman as Hillary may have the future to become president, as makes countless people at a time believed that the capitalist democratic political system was the ablest to represent the direction of the development of human society, and embody the universal value.

What is the universal value? It is the common human value, objective and valid everywhere. It is interpreted in the world as "freedom, democracy, and human rights". However, the real problem lies in the fact that, can the capitalist democratic political system best reflect the universal value? Is the socialist democratic political system not able to reflect it? Since the socialist democratic political system should be superior to capitalist democratic political system from the angle of the class nature of serving the majority of the workforce, why in reality, can it not have the discourse power of the universal values? What we should do facing with the passive situation?

This article believes that we should acknowledge the commonness that the universal value belongs to all human beings and realized the class personality that different users have, which is in line with the dialectical materialism. To break the ideological fence is the key for socialist democratic political system to defeat capitalism democratic political system. That is, on the basis of proletarian universal value, it should critically absorbs capitalist democratic political systems including such historical achievements of human civilization as multi-party competition system, universal suffrage and representative system and the tripartite political system, transform them in a socialist way and create the new socialist democratic political system, namely, the universal socialist democratic system. The system representing the direction of human development and carrying the universal persuasiveness is bound to promote the historical process from capitalism to socialism.

\section{Uncovering the essence of universal value.}

In recent years, controversies on the universal value have become much hotter, displaying a confused situation in ideology. Seen through these phenomena to find the essence, the argument without conclusion lies in the root causes that people have not understood the commonness and personality of the universal value, and different classes have different class attributes though the universal value is expressed in the same words. It is undeniable that "freedom, democracy and human rights" have been proposed by the bourgeoisie. However, the achievements of civilization of any class are actually the mutual wealth of all mankind, which can be continued and developed naturally in any society and in any period of history. As far as these basic principles of the Marxist historical materialism are concerned, it is beyond doubt that "freedom, democracy, and human rights," are the basic elements of the universal value. These basic elements, 
at the individual level, specifically refer to the "right to live", "right to grow", "right to vote", "freedom of religion", and "right of demonstrations", "freedom of speech", and so on; while at the national and state level they refer to the "good governance", "equality and mutual benefit" and "peaceful coexistence" and so on and so forth.

On December 10, 1948, the United Nations including the former Soviet Union and Eastern European socialist countries adopted and promulgated the "Universal Declaration of Human Rights", which requested that it should be "a common standard of achievements for all peoples and all nations" (see the Prelude), confirmed that "everyone is entitled to have all the rights and freedom carried in the Declaration without any distinction of race, color, sex, language, religion, political or other opinions, nationality or social origin, properties, birth or other status" (See Article 2), and clearly pointed out that "the will of the people, which should be expressed in periodic and genuine elections by universal and equal election by secret or free voting, is the basis of governmental authority." (See Article 21). All the socialist countries are now the members of the United Nations, and the supporters of the "Universal Declaration of Human Rights".

Supporting or agreement itself is determined by the class attribute of socialist countries. Should a regime serving the majority of the laboring people have reasons to disapprove the "freedom, democracy, and human rights" related to the interests of the majority of the people? Therefore, the universal value, with "freedom, democracy, and human rights" as the basic contents, has the generality of the common value of all mankind. However, when different countries use it to serve their own ruling class, or when the international commonwealth of different classes utilizes it as a tool to implement the class interests and ideology, the universal value has the different class individuality. For example, relative to the commonness of all the human beings in the "Universal Declaration of Human Rights", the universal value that the United States and other Western capitalist countries advocates and promotes out of class interests is of the typical bourgeois character. Similarly, the universal value advocated by the socialist countries has the proletarian individuality. The commonness and individuality are contradictory to promote the development of things, as is in line with the united law of opposites of dialectical materialism.

The reason why the universal value of the bourgeoisie is deceptive lies in that it steals the name of the common value of human beings uses commonness to conceal its individuality so as to lay a foundation for making ideological confusion of the laboring people especially within the socialist countries. Clearly understanding the deceptive essence of the universal value of the bourgeois class, the deceived working class can get rid of the ideological control from the bourgeoisie at the theoretical level, and the vanguard of the proletariat and the vast majorities of activists can extricate in reality from the temporary incomprehension or even the groundlessness of the universal value to confidently adhere to the universal value of the proletariat on the basis of "freedom, democracy and human rights", thus completely destroying the discourse hegemony of the bourgeoisie on the universal value.

\section{How does the bourgeoisie grasp the discourse power of the universal value?}

The discourse hegemony means the dominant interpretation power of different expressions and standard-setting power, whose essence is the objective embodiment of the development of productive forces and the universal persuasiveness of national system. At this stage, the situation is that the bourgeoisie has mastered the discourse hegemony of the universal value, and been able to in accordance with its own interests declare who meets the demand, who does well and what system is advanced. It also has the objective capability to organize assistance or sanctions of international political, economic, cultural, military, media and other fields according to its own judgment.

How does the situation come into being?

First is due to the objective factors. The capitalist countries since the British bourgeois revolution in 17th century has existed and developed for more than 300 years. Having experienced the development process of all the bourgeois revolutions, three scientific and technological revolutions, colonialism, economic crises, the upsurge of proletarian revolutionary, the two World Wars, the Cold War, the colonial liberation movement, and so on, interacting with the internal and external factors, regulating themselves in the different contradictions, they have developed and improved increasingly and got greatest abundance in wealth by relatively vertical comparison. By contrast, the proletarian socialist country born in 1917 only had experienced a short time of existence and development, and could not compare with the capitalist countries in peak period in productive force and scale. For economic base determines the superstructure, the socialist countries are bound to be in a temporary weak side in the competition of the discourse power of the universal value, so does in political, cultural, diplomatic, military, public opinion fields.

Second is due to the subjective factors. Since the October Revolution in 1917, the proletarian socialist countries in the course of the democratic political system construction and development have experienced twists and detours and paid high cost for its growth. Such typical cases as the Soviet Union cleansing campaign in the 1930s, Poland and Hungary events in 1956, the extreme leftist rule of the Cambodian Communist Party in the 1970s resulting in the death of one million people, ten years of Cultural Revolution in China from 1960 to 1970, and the life tenure at leading posts, personal cult, father-to-son succession in leadership, too much intervention of the state in individual freedom, the 
limited election, the undemocratic way of the election, and the shortage of the rule of law existing to different degrees in socialist countries have seriously hampered the development of socialist democratic political system and damaged the good image of the socialist system in the heart of the working people all over the world. The cost is so high that it may require several generations of the communists to save the loss with painstaking efforts. For example, at the $20^{\text {th }}$ National Congress of the Communist Party of the Soviet Union in 1956, Khrushchev's secret report against Stalin released and shocked the whole world. A large number of members of the Western Communist Parties quitted the Party, and Western communist movement dropped rapidly from the peak of development after World War II, and mauled heavily. Socialism at a time seemed to become genies or ghosts and the international communist movement got into an unprecedented predicament. By now, the "despotic dictatorship" and "secret police" are still the terms that the Western media and some people use to evaluate the socialism.

If we do not adopt the scientific attitude of seeking the truth from the facts to analyze the above-mentioned subjective and objective aspects, we will never understand why the socialist system superior to the capitalist system in nature can not be understand by the majorities of the working people from the capitalist countries, why the working people in the capitalist countries vote for the bourgeois political parties as the ruling party instead of a proletarian party which is actually there. It is just because the socialist democratic political system has not developed to be more convincing than the capitalist democratic political system with the multi-party competition system, universal suffrage and representative system, and separation of powers as the basic contents, the bourgeoisie can grasp the hegemonic discourse of the universal value, and embezzle the commonness of mankind to cover up the individuality of bourgeoisie attribute. The long continuation of this situation results objectively in that such universal value of mankind as "freedom, democracy and human rights" seems to become a capitalist private property on the surface which can be left to the mercy of random, and some socialists lack of scientific theory takes "freedom, democracy and human rights" as the taboo and misunderstand it as the bourgeois ideology.

\section{The theoretical foundation for creating the universal socialist democratic system.}

What socialist democratic political system can be established superior to capitalism not only in nature but also in the actual and visible content and form?

A viewpoint believes that the democratic political system with the former Soviet Union as a prototype for the modern socialist countries is almost a perfect system which does not need fundamental reform but a little regulation and it is certain to be accepted by the masses wholeheartedly. The system and the capitalist democratic political system have, with different names, nothing with each other. This viewpoint ignores the fact that it is its own backwardness that leads to the loss of the discourse right of the universal value, and the fact that the former Soviet Union, the originator of the system, was disintegrated in 1991 where although more people have missed the Soviet Union's stability and great power status, they are unwilling to return to the past political system. Is it simply due to the current stability? Why not think of danger when in safety? To view things from isolated, static, unilateral and superficial perspective is philosophically metaphysical, and is against the principles of Marxist dialectical materialism and historical materialism.

Dialectical materialism and historical materialism are the world outlook and methodology by which the proletariat understands and transforms the world. According to the three basic laws, the unity of opposites, inter-conversion of quality and negation of negation of the dialectical development of the things by the dialectical materialism, capitalism and socialism existing in the unity of human society at the same historical stage are opposite and mutually exclusive. In the two basic fields of social life of economic foundation and superstructure, realistically they criticize mutually and learn from each other but, philosophically, go up spirally from affirmation and negation and the negation of negation, continuing to reach a brand new stage. As we know that the socialist market economy today in the socialist countries results from the dialectic development between the planned economy at the beginning of the socialist counties and the market economy in the capitalist world.

From the perspective of historical materialism, the new relations of production in the socialist market economy result in critically absorbing the kernel of the capitalist market economy and making a socialist transformation in the process of historical development. The kernel is the market economy. It has no class attributes. Whatever class applies it, it will bear the scars of that class. This process has proved that the planned economy, the artificially created relations of production, is not line with the development of productive forces. Then, in the field of superstructure determined by economic base, the socialist democratic political system of the former Soviet model in line with the planned economy was also negative. The new production relations of socialist market economy are in line with the level of development of productivity. They also request that a new socialist democratic political system in the superstructure should agree with them. This is a result that can not be transferred by man's will. It is determined by the objective laws of the social and historical development.

Then, what is the democratic political system in line with the socialist market economy like? Historical materialism believes that the existence and development of a society has evolved and is inseparable from the history. There is a relation of natural continuation and development between society and history because things do come from somewhere. 
According to this scientific theory, the proletariat must, like what it has done in the field of economic infrastructure, find the source from the achievements of civilization in the capitalist social and historical development, specifically speaking, and the source from the capitalist democratic political system based on the bourgeois universal value. The inheriting and developing way is to critically absorb the kernel of the capitalist democratic political system and give a socialist transformation. Here the kernel refers to the universal value with "freedom, democracy and human right" as the basic content and the specific form of expression including the multi-party competition system, universal suffrage and representative election system, the tripartite system, and so on.

In the field of superstructure, Marx and Engels, the great tutors of the working class, set up a good example for us in inheriting and developing the achievements of the bourgeois civilization. In the 1840s, they created dialectical materialism and historical materialism on the basis of critically absorbing the "reasonable kernel" of idealism and dialectics of Hegel, a bourgeois philosopher and the "basic kernel" of mechanical materialism of Feuerbach to establish the Marxist philosophy. In that case, why don't we critically absorb the kernel of the capitalist democratic system and carry out a socialist transformation?

It is worth mentioning that, the old type of the democratic political system itself in the former Soviet Union is not in line with the subjective results according to historical materialism. So as a whole it can be denied. However, as the process of the political experiments by the proletariat, it has become the history of the development of human society and can and should be inherited and developed because the system includes the wisdom of early builders of the proletarian countries and some positive factors such as the rapid and efficient decision-making ability, and the cohesion of dealing with vital matters with all efforts, and so on. Its successful experience and lessons from failures are valuable for the proletariat and conductive to make the socialist transformation on the capitalist democratic system. Therefore, the denial of it is a philosophical negation with affirmative factors in it, as is the proper meaning of the scientific Marxist philosophical proposition.

Acting on the scientific principles of Marxism, after the dialectical process of development, a new universal socialist democratic system has come to the world. The system will be able to meet the requirements of the development of socialist market economy to promote the great development of social productive forces. The system has both the support of the universal value with "freedom, democracy and human rights" as the basic content and the external manifestations superior to the capitalist democratic political system. The more important is that it has the unique advanced nature of representing the interests of majorities of the working people. Since the socialist countries have such institutional advantages, can't they recapture the discourse right of the universal values convincingly?

\section{The assumption of practicing the universal system of socialist democracy in the socialist countries.}

Practice is the sole criterion for testing truth, and any scientific ideas or theories must be verified and improved in practice. But the precondition is that the new theory must come up with specific ideas based on studying and summing up the history and reality, the content of which must be objectively scientific and feasible to win numerous practitioners, then can be applied to practice gradually and get the chance of verification and development. The development of Marxism has such a typical process. And the theory of the universal socialist democratic system must also follow this law. But most important of all is to put forward the idea of practicing the universal socialist democratic system in the socialist countries.

Nowadays all the socialist countries are practicing the democratic political system with the absolute leadership of the proletarian Party at the core. In the premise of the existence of the former Soviet Union, the system was created with the former Soviet Union as a model and the conditions of each country. It has penetrated deeply into all aspects of social life of each socialist country and played a vital role. Therefore, there are some objective difficulties for the universal socialist democratic system to practice in the socialist countries. There exist many specific seemingly insurmountable problems for the cadres and the masses. For example, will it cause instability? How can keep the working class in power if the multi-party system and universal suffrage are implemented? Will the separation of powers lead to inefficiency? Is it necessary to still keep the proletariat's absolute leadership over the people's armed forces? Will the Party organizations at all levels exerting the political role still exist? Will the media, cultural institutions of public opinion and social organizations become the communicators of the bourgeois ideology? Will the superiority that socialism has demonstrated disappear? All of these issues are objective and difficult; however, they are by no means the reasons against progress. The working class, representing the most advanced productive forces and mastering the powerful ideological weapon of Marxist philosophy, should have the ability to overcome these difficulties.

The first difficulty is on the issue of stability. In order to have a smooth transition, we should firmly adhere to the principle of gradual and orderly progress. Objectively, the current socialist countries being surrounded by the capitalist countries, the steady construction of the universal socialist democratic system is conducive to prevent the joint offensive by the bourgeoisie. At the height of historical responsibility, we should know the inevitability of transition to the universal socialist democracy, meanwhile, we can not make an artificial acceleration by going beyond the economic base and superstructure and other objective conditions, and make artificial deceleration ignoring the reality of 
backwardness. The artificial acceleration will make the economic base and the superstructure in sudden inadaptability and cause fundamental chaos. A case in point is the former Soviet Union. It was disintegrated rapidly because the rapid change of political system causing a chaos which can not be overcome in a short term and the collaboration of the domestic and foreign hostile forces. The man-made slowdown will make the superstructure unsuitable for the economic base. According to qualitative and quantitative exchange law of dialectical materialism, the gradually deepening contradictions, when accumulated to a certain volume, will result in an irresistible qualitative change.

By contrast, due to cater for some people's lucky psychology, man-made slowdown is more deceptive and dangerous. The wrong behavior any person has done for mitigation and negative avoidance seems to maintain the stability of socialist countries. But in essence, he has lost the armed thought of dialectical materialism and historical materialism, and become an idealist who stubbornly adheres to his individual wrong consciousness, as conceals and connive the continuous growth of social contradictions, and finally facilitates the qualitative change of the capitalist restoration. What is more awful is that the paralytic effect of a longer seemingly stability, if there forms the artificial slowdown of a large group of people in socialist countries, before a qualitative change comes, capitalism will be restored in some countries. It is a domino effect. For example, the socialist countries in former Soviet camp had not carried out major reform for several decades, resulting in unsolvable conflicts. The qualitative change of these countries actually led to the discoloration of the former Soviet Union, Eastern Europe, Mongolia and about ten African socialist countries (such as Angola, Benin, Mozambique, Congo) which had not been acknowledged by orthodox. The trend of historical development is irresistible so only by conforming to the trend and making a timely reform, can socialism be invincible.

The second difficulty is on the multi-party competition system and the universal representative suffrage. Since we know the limitations of the capitalist democratic system lies in its class attribute, as long as we change the attribute, some progress factors of it will be critically absorbed by the socialist democratic system. The multi-party competition system in socialist countries can be expressed that a number of proletarian party with different names, such as the Communist Party, the Labor Party, the People's Revolutionary Party and so on, must identify with Marxist but can have minor differences in specific policies or strategies. Various political parties can display to their best the features of implementation and the personal charisma of the candidate politicians before the masses of working people by rich forms and transparent process of the election, a free and fair direct universal suffrage supervised by the state election administration and the UN observers. The representatives, produced by the universal suffrage, form the socialist legislature, which can be named as the people's congress, congress, or legislative assembly. The political party holding the majority of the seats comes into power. If there is no majority of seats, combined ruling can be formed. In the premise of keeping the socialist nature, the local democratic elections and the political system at all levels can learn from the mature system of capitalist countries.

As the national bourgeoisie is under the leadership of the proletariat in the socialist countries and the international balance of power makes the socialist countries not get rid of the malicious interference by the joint forces of international bourgeoisie, the non-proletarian political parties can not be allowed to appear temporarily but the advanced elements of the national bourgeoisie can be absorbed into the proletarian party politics to participate in the politics. It is similar with what bourgeoisie has done to ensure its position as a ruling party in the capitalist countries. Both embody that the ruling class has the will to guarantee the class attitude of the power. In order to be more deceptive and paralytic, what the bourgeoisie has done is to allow the proletarian party to exist in a certain range. But as long as the proletarian party has any chance to seize political power, the bourgeoisie will take all measures to strangle it. Examples about it are many, too numerous to be recorded after World War II. Proper cases in point are that America had anti-communist McCarthyism during the period of upsurge of the communist movement after World War II; the Communist Party of France was blocked to take the power by the International Joint bourgeois in 1947; in 1965 the right-wing Indonesian army supported by the United States slaughtered 300,000 communists; in 1973 the United States helped the right-wing military coup of Chile to overthrow the left-wing elected Allende government; in 1996 the US-led international bourgeois threatened and induced the Russian voters and the Russian Communist Party was defeated unfortunately. All these facts have proved that when the class rule is threatened, the bourgeoisie will tear off the disguise of "freedom, democracy and human rights" and adopt the measures to make a joint and unscrupulous repression. Of course, this is also determined by the international class power balance and the reflection that economic base determines the superstructure. Similarly, when the proletariat has dominant force, it can also allow the national bourgeois political parties to exist within reasonable scope. Since the participating Parties existing in socialist countries have been the socialist organizations of workers, they can be totally transformed into one or more political parties with Marxism as the guiding ideology, and can also be incorporated into other Marxist political parties. By contrast, they are willing to conduct such changes.

The third difficulty is on the tripartite political system. The power balance system represented by the tripartite political system of administration, legislation and jurisdiction has the theoretical basis, that is, the consensus of all mankind of absolute power resulting in absolute corruption. The capitalist tripartite system has left the impression that the national decision-making is of low efficiency, as is determined by the class nature it serves the bourgeois. In the development 
history of capitalist countries, the lobbying organizations sanding for various interests groups of bourgeois always control the state operation. When the bourgeoisie is consistent in the interests, the three powers will coordinate one another with a high efficiency. But when the bourgeoisie is inconsistent or incompatible with the interests, the three powers must be highly inefficient, leading to low efficiency of decision-making, thus safeguarding the interests of the bourgeoisie in the name of democracy. For example, the proliferation of firearms in the United States causes the death of 30,000 people each year. But why cannot the comprehensive firearm ban act be passed because the government, congress and the Supreme Court pass buck? The fundamental reason under the pretext of the outdated constitutional rights is because it violates the interests of the military capitalists. The National Rifle Association (NRA), a powerful lobbying organization in the United States is the right speaker standing for their interests.

However, the socialist separation of powers is of the proletarian attribute because government, parliament and judicial bodies are composed by the representatives on behalf of the interests of the proletariat and the working people, which has determined that as long as it is in line with the interests of the working people the socialist powers will coordinate with one another with high efficiency. Good cases in points are in these aspects of combating corruption and building a clear government, improving the people's livelihood and promoting the development. On the condition that it is not in line with the interests of the working people, the tripartite socialist powers will play a role of checks and balances. It is by no means inefficient, but to prevent major errors and achieve a scientific and democratic decision-making. In the system, there will be no such a phenomenon that individuals or groups of high social position can change the state policies and the historical process on their own knowledge. For example, Mikhail Gorbachev, the former leader who was yearning for social democracy and his small group in the former Soviet Union solely promoted the gradual change of the Soviet camp to the drastic collapse. In this case, it is the Soviet mode which is lack of checks and balances of powers that buried the Soviet Union.

Then what kind of tripartite political system should be implemented? There are various kinds of tripartite systems, such as American mode, British mode, French mode, Russian mode and the variant version of Mr. Sun Yat-sen's "five powers", etc. Socialist countries should set up their own according to the respective national conditions by utilizing the experience of others. This is the essence of science of Marxist combination of theory with practice.

The fourth difficulty is about the problem of the proletarian leadership over every social aspect. Proletarian leadership over all walks of society is the foundation to reflect the socialist superiority. In a universal socialist democratic system, the leadership of the proletariat will show up in a new form in line with the universal value. First, all the proletarian political organizations of the Communist Party, the Communist Youth League, the Young Pioneers existing in governments, army, legal organizations, enterprises and the social institutions will be retained. They no longer belong to any specific political party but to the vanguard of the proletariat, an entirety, existing in a form of many political parties of the working class. The proletarian political organization is no longer a political party. Therefore, the name of "the Communist Party" will not be reused any more. Instead, it can be named as the "communist alliance." The titles of the Communist Youth League and the Young Pioneers are of neutrality and can be used continuously. The essence of these organizations is to extend and display its neutral position in the state machine of competitive parties and social units as the proletarian will of the ruling class. They will no longer exercise the administrative functions that had not belonged to them. But they will exert their exemplary roles in the ideological mobilization, publicity and education, mass organizations, etc.

Secondly, these new proletarian political organizations will be led by the socialist congress, which embodies the entire will of the proletariat. Specifically speaking, the actual administration is the committee of ideology in congress. The ideological committees at every level are the departments in charge of the ideology. As these political organizations no longer have administrative power, so they will not hinder the governments in reality and have no interference with the lawful activities of social units and social groups. At the same time, as the political organizations with widespread influence over the whole society, they and their congress will be supervised and restricted by the executive and judicial powers, concretely manifesting the separation of powers.

In the universal socialist democratic system, many non-public but lawful private media, institutions of public opinion in culture, independent trade unions, and civil societies will come into being. The state administration in charge of ideology should lead the establishment of proletarian political organizations in all the scale social units and social groups of all the ownerships so that the advanced elements of the proletariat can find their home organizations and ideological position. This will basically guarantee that the social units and social groups are of socialist nature and subject to the leadership of the proletariat. As long as they do not object to the state nature and break the law, they may supervise the three powers or even can attack the ruling party and the state leaders and become the true "fourth power".

Furthermore, the socialist state constitution can clearly prescribe that any behavior of individuals or political organizations that is likely to harm the fundamental principles of the dominant position of the socialist ideology and the state socialist nature can be banned only through a simple majority of the congress, as is in line with the principle of democracy. In a country with sound national democratic political system where "freedom, democracy and human 
rights" are fully respected, the social contradictions will be resolved timely. It is not convincing to publicize opposition to the state nature. The capitalist countries ruled by a small number of people can achieve that and keep a long-term stability, so do the majority ruling socialist states.

Such a universal socialist democratic system experiencing the process from theory to practice will have the advantages of the two established democratic political systems of socialism and capitalism, which is consistent with the standard of the universal value and can ensure the socialist nature of a country to be unshakable. The laboring people can not only fully enjoy the "freedom, democracy and human rights", the rapid and efficient decision-making, the cohesion of concentrating efforts on vital matters, the ruling aim of serving the people, the unity and mutual aid when disaster strikes, the assistance from the soldiers who can give their lives for the benefits of the people, and the exemplary role of the vanguard. All have embodies the superiority of socialism. In such cases, the viewpoints of finding some excuses of national conditions and those who believes they reject the democracy because the working people are lack of quality are worth nothing. At the same time, those who can not find the right direction of the socialist democracy both in theory and practice are forced to be influenced by the bourgeois democratic thought can also find their way out. Of course, those comrades with such viewpoints, if their intention is for the protection of the socialism, the masses of working people will embrace them to be back to build and enjoy the universal socialist democratic system.

\section{How can the universal socialist democratic system be put into general practice in the world?}

As the vanguard of the proletariat, at any time, the Communist Party should not forget the proletarian internationalism, and the ultimate mission of liberating all mankind. Marx and Engels wrote in the "Communist Manifesto", " the workers do not have the motherland", and "the proletarian class itself is national". The seemingly contradictory discourse has dialectically revealed that the proletariat is of the national, international and global nature. They also wrote, "what is the relationship between the communists and the entire proletariat?", "they do not have any interests different from those of the entire proletariat", "on the one hand, in the struggle by the proletariat in every country, what the communists stress and adhere to is the interests of the whole proletariat regardless of nations; on the other hand, at every stage of the proletariat fighting against the bourgeoisie, the communists have always represented the interests of the entire movement."

Then, what is the common interests for the world proletariat at this stage? The common interests, in the basic fields of social life in the economic base and superstructure, is to desiderate to find and verify the advanced production relations and the democratic political system in line with them to make the working people especially those in the capitalist countries be convinced to consciously promote the historical process that socialism can replace the capitalism. At present, the advanced production relation that the proletariat has found is the socialist market economy, and the advanced democratic political system is the universal socialist democratic system. The communists are the proletarian vanguard to achieve the common interests. Of them, communists in the modern socialist countries are the major force because they have the power and can practice and develop the socialist market economic system and the universal socialist democratic system. At present, the socialist market economy has achieved initial results, and it is important for the universal socialist democratic system to keep up with it.

In the current phase of history, the objective law of man's historical development and the proletarian internationalism demand that the communists, the fearless proletariat, should practice the truth that socialism is superior to capitalism. As long as the socialist countries establish the universal socialist democratic system in line with the socialist market economy, the interaction of the two is bound to promote the huge leap in productivity, the great abundance of material and spiritual civilizations, and completely surpass all capitalist countries in the economic base and superstructure. At that time, the working people in capitalist countries will be aware of the advancement from capitalism to the socialism, as is bound to be a great leap from the inevitable kingdom to the realm of freedom. And capitalism will inexorably be replaced by socialism.

In this practice, there may arise some directions of development as follows.

The first one is the counterattack of the bourgeois. The development of human society shows that the old ruling class is reluctant to withdraw from the stage of history. When the socialist countries completely surpass all the capitalist countries, the working people in the capitalist countries will vote the proletarian party to be the ruling party and the proletarian party in power will more confidently implement the policies and reforms to serve the working people, which will inevitably violate the interests of the bourgeoisie. Bourgeois conservative forces will not be reconciled to be defeated and they will united and adopt various means to give obstruction and sabotage. However, the social and historical development has reached a higher stage, the working people have arrived at a new height of understanding, and the international class balance of power is conducive to the proletariat, so the obstruction and sabotage will not get successful. When the conservative forces of bourgeoisie employ the violent means against the revolution, the masses of working people will be forced to use revolutionary violence to wipe them out. In other words, in this case, the transition from capitalism to socialism will be completed by violent revolutionary means. 
The second one is the possibility of a peaceful transition. In the process of the social and historical development, as to the strength of the bourgeoisie and the proletariat, the decline of one means the growth of the other. In some countries, because the bourgeois conservatives are not strong enough to suppress the working people by means of violence, the working people can put the political party of their own class in the ruling party's position for a peaceful long term. The bourgeois political parties will be increasingly marginalized because the class they service is in a position of the minority of population. In the new socialist society, their existence is only for obtaining the rights they should have. It is no longer a social force and will finally wither away with the disappearance of the bourgeois class.

The third one is about the early breakthrough to some local scope. At present, in some under-developed countries of capitalism, or even in some developing countries where feudal residual powers still exist, the universal socialist democratic system may have made early breakthroughs. Today when the universal value with "freedom, democracy and human rights" as the basic content is established, some communist parties that took the power through the armed struggle is not likely to set up the political and economic systems of the former Soviet mode. It is of great possibility that they may become a pioneer of the universal socialist democratic system. And in some countries where bourgeois political parties are not strong, the proletarian parties may also be elected to be the ruling party. The above two cases have appeared in Nepal and the Republic of Moldova and other countries, as is worth noticing. However, the early breakthrough is rather instable, as is determined by the balance of strength of today's world classes. Whether they can steadily grow depends on their performance in reign and the demonstration of the whole working class in the world and its vanguard. Particularly, the performance of the Communist Party of socialist countries is of great importance.

\section{Conclusion.}

From the perspective of the entire proletariat, applying the world outlook and methodology of Marxist philosophy, combining history with reality, we can come to the conclusion that the universal socialist democratic system will be a new democratic political system created by the proletariat, which is universally convincing and feasible in the world and stands for the direction of the development for the human society. It is an interpretation given by the proletariat in the scope of superstructure that the universal value of mankind occupies the dominant position, a dominant standard of value. In other words, the universal socialist democratic system is of the universal significance for all human beings. It will together with the socialist market economy promote the historical process of human society from capitalism to socialism.

\section{References}

Baidu net.

Cao, Weidong. (2007). History of the World. Beijing: Haichao Press.

Deng, Shuhua. And Xie Hairong. (2008). Theory of Scientific Socialism and its Practice. Beijing: National Defense Industry Press.

Fei, Xinlu. (2008). Rise and Fall of the French Communist Party- the Historical Evolution and Innovation of the French Communist Party. Beijing: the People's Publishing House.

Selected Works of Lenin. (1995). Beijing: the People's Publishing House. Vol.1-4. Selected Works of Mao Zedong. (1964). Beijing: the People's Publishing House.

Selected Works of Marx and Engels. (1995). Beijing: the People's Publishing House. Vol.1-4

Wang, Side and Qian Hong. (1993). The Contemporary World History. Beijing: Higher Education Press.

Wells. (2007). The Outline of History. Translated by Man Yeping and Li Min. Xi'an: Shanxi Normal University Press.

$\mathrm{Xu}$, Chongwen. (1995). Analyzing the Democratic Socialism. Chongqing: Chongqing Publishing House.

Zhao, Haiyue. (2007). Research on the Foreign Contemporary Marxism. Changchun: Jilin University Press.

Zheng, Zhigang. (2007). Theories and practices of socialism in the world. Beijing: the People's Publishing House. 